\title{
An Overview of Indonesian's Challenging Future:
}

\author{
Management of Artificial Intelligence in Education
}

\author{
Dian Indriyani*, Keisha Dinya Solihati \\ Polytechnic STIA LAN Jakarta \\ National Institute of Public Administration Indonesia \\ Jakarta, Indonesia \\ *dian.lanri@gmail.com, keisha.dinya@gmail.com
}

\begin{abstract}
Indonesia is the largest archipelagic country in the world, with diverse profiles of ethnic groups and population distribution. Based on data 530,000 schools were deactivated due to the COVID 19 pandemic and affected 68 million students. The AI Management in improving the quality of education in Indonesia has never been investigated before. Therefore, the use of Artificial Intelligence (AI) in this sector can be a way to improve student capability. Some obstacles that are seen in the implementation of AI in the education sector. Purpose of this research is that it can contribute as references and recommendations for government in making policies on $\mathrm{AI}$ in education for future. Based on the research analysis using SWOT method, it is concluded that AI can can encourage capacity building and capabilities of Indonesian students in the future. However, implementation in Indonesia needs more improvement to ensure the artificial intelligence in education system. In integrating AI with education, we must focus on certain aspects: 1) ensure the inclusive and equitable use of $A I$ in education; 2) utilize AI to improve education and learning; 3) Promote development of skills for work and life in the AI era 4) Maintaining the use of transparent and auditable education data and 5) develop a policy framework to manage AI implementation in education sector. Purpose of this research is that it can contribute as a reference and recommendation for stakeholders and government in making policies on $\mathrm{AI}$ in education for the future.
\end{abstract}

Keywords-Artificial Intelligence, education technology, elearning platform, SWOT

\section{INTRODUCTION}

The use of information and communication technology to provide educational services has a great potential to improve the learning outcomes. Healing of technological infrastructure for internet-based distance education every day, eliminating of barriers of time and place for education, having opportunity to reach a wide audience and data's being continually updated has made internet-based education attractive. Especially in this Covid-19 pandemic era, the ICT usage for effective education using technology is an increasingly urgent need. This situation forces a rapid and widespread increase in the use of education technology. While artificial intelligence (AI) has received increased attention, discursive circulation, and practical application [1].

In accordance with The Ministry Joint Decree 4 the government's main priority is to prioritize the public health and safety so that it does not allow offline teaching and learning activities to take place normally. Therefore, in helping students in the remote learning system, the Indonesian Ministry of Education and Culture has collaborated with at least $12 \mathrm{e}$ learning application provider platforms that are ready to be accessed by students throughout Indonesia, namely, Rumah Belajar, Meja Kita, Icando, IndonesiaX, Google for Education, Kelas Pintar, Microsoft Office 365, Quipper School, Ruangguru, Sekolahmu, Zenius, and Cisco Webex.

The increasing usage of educational technology platforms is driving the massive growth of AI platforms based on educational technology. From a futuristic point of view, AI is the key to success in managing education in the future, which makes it easier for users to interact and learn with various platforms and will be part of everyone's daily habit. As underlined by Housman [2], "AI is capable of two things: (1) automating repetitive tasks by predicting outcomes on data that has been labeled by human beings, and (2) enhancing human. Therefore, this study aims to explain the challenges of $\mathrm{AI}$ management in education in order to increase competitive advantage in the future.

\section{THEORETICAL FRAMEWORK}

\section{A. Artificial Intelligence}

Artificial Intelligence (AI) is a new innovation in computer science which is very important in the present era and the future. Derived from the Latin "intelligo" which means "I understand", AI has the aim of understanding and taking action. The development of AI stems from the emergence of computers around the 1940's. At this time, attention is focused on the ability of computers to do something that can be done by humans [3]. In this case, the computer can adapt the ability of human intelligence and behavior to solve problems. Nabiyev [4] roughly defines AI as the ability of a computer-controlled device to perform tasks in a human-like manner. As indicated 
by the author, human-like qualities include mental processes like reasoning, meaning making, generalization, and learning from past experiences. Russell and Norvig [5] describe the term $\mathrm{AI}$ as Machine Intelligence, or Computational Intelligence, that embraces various subfields wherein learning takes place and "specific tasks, such as playing chess, proving mathematical theorems, writing poetry, and diagnosing diseases, can be performed" (p. 2). Nilsson [6] defines AI as the entirety of an algorithmic construction copying human intelligence. AI embraces the construction of the informationprocessing theory of intelligence. In other words, raw data, received from any user, is filtered by a device, made meaningful, and processed before finally becoming cooked data capable of meeting the demands of users.

During the 20th century, a number of definitions of Artificial Intelligence (AI) were proposed. One of the early definitions of AI which is still popular is: "making computers think like humans", as evidenced by the large number of science fiction films promoting this view [7]. In addition, Artificial Intelligence (AI) is a study of how to make computers do things which, at present, humans are better. Meanwhile, the field of artificial intelligence or AI, is not only for understanding something but also for building intelligence entities. A system is called rational if the system is doing "the right thing", according to what it knows. A human-centered approach or a humane approach is part of empirical science, which involves observations and hypotheses about human behavior. The rationalist approach involves a combination of mathematics and engineering [8]. Some areas in AI are [7]: Expert System, Computer Vision, Natural Language Processing (NLP), Robotics and Navigation Systems, Games, and Theorem Proving.

\section{B. Education Learning Platforms}

According to Bri et al. [9] e-learning platforms can be defined as "the hardware and software environment designed to automate and manage development academic formation activities. The software must administer, distribute and check activities for face-to-face formation or e-learning in an organization. The main functions are, manage and register users, resources and formation activities, access check, control and monitoring learning process, doing evaluation, informs and managing communication services." It is a technological response that integrates different management tools, facilitating learning development, distributed using information of a very diverse nature. In short, eLearning platforms are the server software which is mainly in charge of user management, management of courses and communication services, providing the eLearning scene with its necessary support $[10,11]$. This definition of e-learning platform needs to be widely developed regarding the multiplex components and characteristics that can be brought together. Whilst still evolving, e-learning platforms have reached a certain standardization of functions and tools.

\section{SWOT Analysis}

Rangkuti [12] explains that SWOT analysis is the identification of various factors systematically to formulate an organizational strategy. These factors include strengths, weaknesses, opportunities, and threats. The four factors form the acronym SWOT (strengths, weaknesses, opportunities, and threats). David [13] suggests limitations in identifying SWOT factors as follows:

- Strength: is resources, skills, or other advantages related to company competitors and the market needs that can be served.

- Weakness: limitations or deficiencies in resources, skills, and capabilities that effectively hinder company performance. These limitations can be in the form of facilities, financial resources, management capabilities and marketing skills.

- Opportunities: important situations that benefit in a corporate environment. Important trends are one source of opportunities, such as changes in technology and increased relationships between companies and buyers or suppliers.

- Threats: Important situations that do not benefit in a corporate environment. Threats are a major deterrent to the company's current or desired position.

\section{METHODOLOGY}

This study uses a literature study and data mining approach to determine the implementation of artificial intelligence in education. After collecting data through the study of literature, then an analysis of the implementation of artificial intelligence is carried out. The aim is to analyze and explore the artificial intelligence system in education through the SWOT method to prepare future challenges.

\section{FINDINGS}

This section presents the 5 biggest education platform that use in Indonesia (Rumah Belajar, Ruangguru, Quipper, Cisco Webex, and Zenius) and explains the trends in past 12 months (See Figures 1-4).

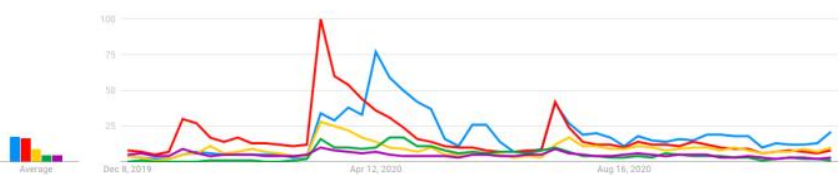

Fig. 1. Comparison by interest over time since 2 Dec 2019-2020. Source: Google Trends Analysis, 2nd Dec 2020 
Fig. 2. Comparison breakdown by subregion.

Source: Google Trends Analysis, 2nd Dec 2020

Another visualization of usage presentation from each platforms can be seen in Tables 1 below.

TABle I. PERCENTAges of 5 EdUCATION PlatForm By SUbReGion

\begin{tabular}{|c|c|c|c|c|c|}
\hline Subregion & $\begin{array}{l}\text { Rumah } \\
\text { Belajar }\end{array}$ & $\begin{array}{c}\text { Ruang } \\
\text { guru }\end{array}$ & Quipper & $\begin{array}{c}\text { Cisco } \\
\text { Webex }\end{array}$ & Zenius \\
\hline Aceh & $27 \%$ & $41 \%$ & $21 \%$ & $5 \%$ & $6 \%$ \\
\hline Bali & $32 \%$ & $21 \%$ & $20 \%$ & $22 \%$ & $5 \%$ \\
\hline $\begin{array}{c}\text { Bangka } \\
\text { Belitung } \\
\text { Islands }\end{array}$ & $39 \%$ & $28 \%$ & $16 \%$ & $10 \%$ & $7 \%$ \\
\hline Banten & $34 \%$ & $33 \%$ & $13 \%$ & $9 \%$ & $11 \%$ \\
\hline Bengkulu & $39 \%$ & $28 \%$ & $22 \%$ & $3 \%$ & $8 \%$ \\
\hline $\begin{array}{c}\text { Central } \\
\text { Java }\end{array}$ & $33 \%$ & $33 \%$ & $18 \%$ & $7 \%$ & $9 \%$ \\
\hline $\begin{array}{c}\text { Central } \\
\text { Kalimantan }\end{array}$ & $37 \%$ & $37 \%$ & $10 \%$ & $9 \%$ & $7 \%$ \\
\hline $\begin{array}{c}\text { Central } \\
\text { Sulawesi } \\
\end{array}$ & $30 \%$ & $28 \%$ & $33 \%$ & $4 \%$ & $5 \%$ \\
\hline East Java & $38 \%$ & $30 \%$ & $18 \%$ & $6 \%$ & $8 \%$ \\
\hline $\begin{array}{c}\text { East } \\
\text { Kalimantan }\end{array}$ & $38 \%$ & $30 \%$ & $15 \%$ & $10 \%$ & $7 \%$ \\
\hline $\begin{array}{c}\text { East Nusa } \\
\text { Tenggara }\end{array}$ & $37 \%$ & $47 \%$ & $9 \%$ & $3 \%$ & $4 \%$ \\
\hline Gorontalo & $28 \%$ & $35 \%$ & $34 \%$ & $3 \%$ & $0 \%$ \\
\hline Jambi & $37 \%$ & $41 \%$ & $8 \%$ & $6 \%$ & $8 \%$ \\
\hline Lampung & $47 \%$ & $33 \%$ & $9 \%$ & $4 \%$ & $7 \%$ \\
\hline Maluku & $35 \%$ & $32 \%$ & $19 \%$ & $9 \%$ & $5 \%$ \\
\hline $\begin{array}{c}\text { North } \\
\text { Kalimantan } \\
\end{array}$ & $27 \%$ & $12 \%$ & $45 \%$ & $13 \%$ & $3 \%$ \\
\hline $\begin{array}{c}\text { North } \\
\text { Maluku }\end{array}$ & $36 \%$ & $57 \%$ & $7 \%$ & $0 \%$ & $0 \%$ \\
\hline $\begin{array}{c}\text { North } \\
\text { Sulawesi }\end{array}$ & $37 \%$ & $40 \%$ & $13 \%$ & $5 \%$ & $5 \%$ \\
\hline $\begin{array}{c}\text { North } \\
\text { Sumatra }\end{array}$ & $28 \%$ & $33 \%$ & $25 \%$ & $7 \%$ & $7 \%$ \\
\hline Рариа & $28 \%$ & $29 \%$ & $30 \%$ & $7 \%$ & $6 \%$ \\
\hline Riau & $29 \%$ & $37 \%$ & $18 \%$ & $9 \%$ & $7 \%$ \\
\hline $\begin{array}{c}\text { Riau } \\
\text { Islands }\end{array}$ & $38 \%$ & $32 \%$ & $9 \%$ & $11 \%$ & $10 \%$ \\
\hline $\begin{array}{l}\text { South East } \\
\text { Sulawesi }\end{array}$ & $44 \%$ & $29 \%$ & $19 \%$ & $4 \%$ & $4 \%$ \\
\hline $\begin{array}{c}\text { South } \\
\text { Kalimantan } \\
\end{array}$ & $36 \%$ & $37 \%$ & $10 \%$ & $8 \%$ & $9 \%$ \\
\hline $\begin{array}{c}\text { South } \\
\text { Sulawesi } \\
\end{array}$ & $31 \%$ & $30 \%$ & $24 \%$ & $9 \%$ & $6 \%$ \\
\hline South & $39 \%$ & $32 \%$ & $15 \%$ & $7 \%$ & $7 \%$ \\
\hline
\end{tabular}

\begin{tabular}{|c|l|l|l|l|l|}
\hline Subregion & $\begin{array}{c}\text { Rumah } \\
\text { Belajar }\end{array}$ & $\begin{array}{c}\text { Ruang } \\
\text { guru }\end{array}$ & Quipper & $\begin{array}{c}\text { Cisco } \\
\text { Webex }\end{array}$ & Zenius \\
\hline Sumatra & $27 \%$ & $35 \%$ & $13 \%$ & $14 \%$ & $11 \%$ \\
\hline $\begin{array}{c}\text { Special } \\
\text { Region of } \\
\text { Jakarta }\end{array}$ & $28 \%$ & $29 \%$ & $11 \%$ & $22 \%$ & $10 \%$ \\
\hline $\begin{array}{c}\text { Special } \\
\text { Region of } \\
\text { Yogyakarta }\end{array}$ & $37 \%$ & $32 \%$ & $13 \%$ & $8 \%$ & $10 \%$ \\
\hline West Java & $40 \%$ & $37 \%$ & $7 \%$ & $6 \%$ & $10 \%$ \\
\hline $\begin{array}{c}\text { West } \\
\text { Kalimantan }\end{array}$ & $32 \%$ & $37 \%$ & $17 \%$ & $8 \%$ & $6 \%$ \\
\hline $\begin{array}{c}\text { West Nusa } \\
\text { Tenggara }\end{array}$ & $32 \%$ & $38 \%$ & $27 \%$ & $3 \%$ & $0 \%$ \\
\hline West Papua & $38 \%$ & $27 \%$ & $26 \%$ & $4 \%$ & $5 \%$ \\
\hline $\begin{array}{c}\text { West } \\
\text { Sulawesi }\end{array}$ & $41 \%$ & $32 \%$ & $15 \%$ & $4 \%$ & $8 \%$ \\
\hline $\begin{array}{c}\text { West } \\
\text { Sumatra }\end{array}$ & $\mathbf{5 3 1 \%}$ & $\mathbf{4 9 7 \%}$ & $\mathbf{2 6 5 \%}$ & $\mathbf{1 1 0 \%}$ & $\mathbf{9 7 \%}$ \\
\hline $\begin{array}{c}\text { Market } \\
\text { Capital }\end{array}$ & $\mathbf{5 0}$ & $5 \%$ G & \\
\hline
\end{tabular}

Source: Google Trends Analysis, 2nd Dec 2020

- rumah belajar $\bullet$ Ruangguru Q Quipper Cisco Webex $\bullet$ zenius

Fig. 3. Comparison breakdown by city.

Source: Google Trends Analysis, 2nd Dec 2020

TABLE II. PERCENTAgES OF 5 EdUCATION PlatForm By City

\begin{tabular}{|c|l|l|l|l|l|}
\hline Subregion & $\begin{array}{c}\text { Rumah } \\
\text { Belajar }\end{array}$ & $\begin{array}{c}\text { Ruangg } \\
\text { uru }\end{array}$ & Quipper & $\begin{array}{c}\text { Cisco } \\
\text { Webex }\end{array}$ & Zenius \\
\hline Balikpapan & $37 \%$ & $26 \%$ & $15 \%$ & $11 \%$ & $11 \%$ \\
\hline $\begin{array}{c}\text { Bandar } \\
\text { Lampung }\end{array}$ & $39 \%$ & $31 \%$ & $9 \%$ & $12 \%$ & $9 \%$ \\
\hline Bandung & $31 \%$ & $33 \%$ & $14 \%$ & $10 \%$ & $12 \%$ \\
\hline Banjarmasin & $35 \%$ & $37 \%$ & $12 \%$ & $8 \%$ & $8 \%$ \\
\hline Batam & $31 \%$ & $31 \%$ & $10 \%$ & $19 \%$ & $9 \%$ \\
\hline Bekasi & $33 \%$ & $31 \%$ & $21 \%$ & $7 \%$ & $8 \%$ \\
\hline Bogor & $33 \%$ & $35 \%$ & $11 \%$ & $11 \%$ & $10 \%$ \\
\hline Denpasar & $25 \%$ & $27 \%$ & $13 \%$ & $28 \%$ & $7 \%$ \\
\hline Depok & $34 \%$ & $33 \%$ & $9 \%$ & $10 \%$ & $14 \%$ \\
\hline Jakarta & $28 \%$ & $34 \%$ & $14 \%$ & $14 \%$ & $10 \%$ \\
\hline Kediri & $42 \%$ & $31 \%$ & $12 \%$ & $5 \%$ & $10 \%$ \\
\hline Klaten & $29 \%$ & $33 \%$ & $25 \%$ & $7 \%$ & $6 \%$ \\
\hline Makassar & $30 \%$ & $34 \%$ & $21 \%$ & $9 \%$ & $6 \%$ \\
\hline Malang & $27 \%$ & $31 \%$ & $24 \%$ & $8 \%$ & $10 \%$ \\
\hline Medan & $35 \%$ & $32 \%$ & $23 \%$ & $9 \%$ & $11 \%$ \\
\hline Padang & $28 \%$ & $28 \%$ & $14 \%$ & $10 \%$ & $10 \%$ \\
\hline Palembang & $39 \%$ & $32 \%$ & $13 \%$ & $10 \%$ & $6 \%$ \\
\hline Pekanbaru & $29 \%$ & $36 \%$ & $15 \%$ & $14 \%$ & $6 \%$ \\
\hline Semarang & $24 \%$ & $35 \%$ & $20 \%$ & $12 \%$ & $9 \%$ \\
\hline Sidoarjo & $28 \%$ & $28 \%$ & $20 \%$ & $9 \%$ & $15 \%$ \\
\hline
\end{tabular}


TABLE II. Cont.

\begin{tabular}{|c|l|l|l|l|l|}
\hline Subregion & $\begin{array}{c}\text { Rumah } \\
\text { Belajar }\end{array}$ & $\begin{array}{c}\text { Ruangg } \\
\text { uru }\end{array}$ & Quipper & $\begin{array}{c}\text { Cisco } \\
\text { Webex }\end{array}$ & Zenius \\
\hline $\begin{array}{c}\text { South } \\
\text { Tangerang }\end{array}$ & $25 \%$ & $37 \%$ & $11 \%$ & $13 \%$ & $14 \%$ \\
\hline Surabaya & $35 \%$ & $30 \%$ & $17 \%$ & $8 \%$ & $10 \%$ \\
\hline Surakarta & $32 \%$ & $31 \%$ & $16 \%$ & $10 \%$ & $11 \%$ \\
\hline Tangerang & $32 \%$ & $31 \%$ & $12 \%$ & $13 \%$ & $12 \%$ \\
\hline Taskimalaya & $56 \%$ & $15 \%$ & $17 \%$ & $5 \%$ & $7 \%$ \\
\hline $\begin{array}{c}\text { Market } \\
\text { Capital }\end{array}$ & $\mathbf{8 1 7 \%}$ & $\mathbf{7 8 2 \%}$ & $\mathbf{3 8 8 \%}$ & $\mathbf{2 7 2 \%}$ & $\mathbf{2 4 1 \%}$ \\
\hline
\end{tabular}

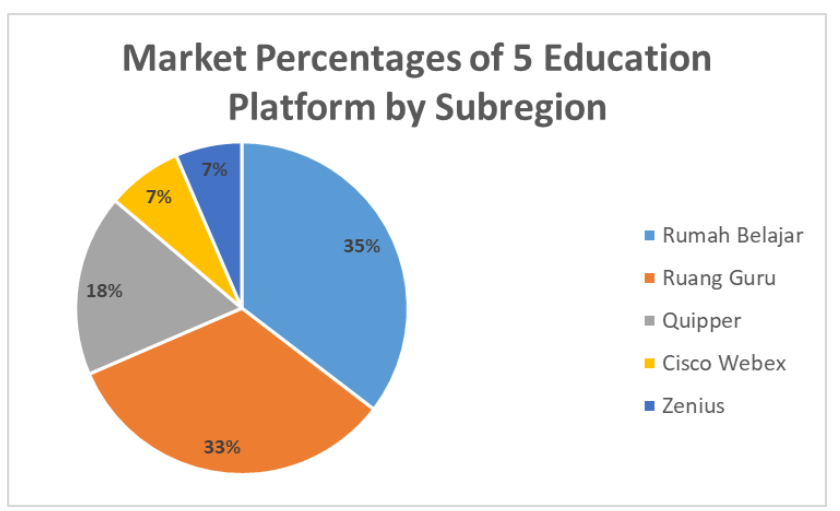

Fig. 4. Market penetration compilation.

Source: Researcher, 2nd Dec 2020.

\section{DISCUSSION}

Identification of the COVID 19 first case occurred in Indonesian citizens was on March 2nd, 2020, then the PSBB (Large-Scale Social Restrictions) policy was stipulated in DKI Jakarta on April 10, 2020 which was then implemented in other provinces as well. These dates serve as reference points in observing the use of educational technology platforms. Based on the data from Google trends as shown in figure 5 , it is clearly seen that there was an increase in the use of educational technology platforms since March 8-14, 2020. It was occurred because of the government policy stated in the Ministerial Joint Decree to continue the teaching and learning process with a distance learning system or online based education. The limited space for movement causes all students were required to learn from various sources in order to fulfill the learning outcomes.

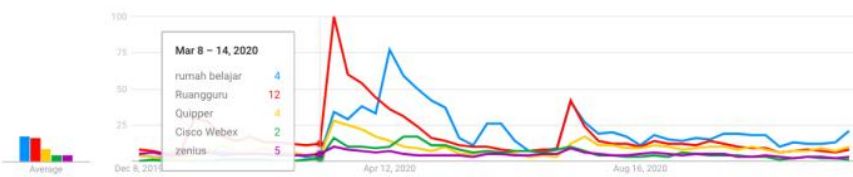

Fig. 5. Data google trends on 8-14 March 2020.

Source: Google Trends Analysis, 2nd Dec 2020

The increased use of the five platforms is spread evenly throughout Indonesia. Massive rate of use is accessed mostly in both cities and subregions of Indonesia. Tables 1 and 2 illustrate the potential for comparative use, it is known that Rumah Belajar and Ruangguru are leaders in the market capital of the e-learning platform industry. Rumah Belajar has accumulated market capital of $35 \%$ in subregional areas and $33 \%$ in urban areas, while Ruangguru has market capital of $33 \%$ in subregional areas and $31 \%$ in urban areas. This market capital calculation illustrates the great potential in the development of $\mathrm{AI}$ in education (e-learning platform).

In addition, there is a gap between the use of e-learning platform in urban and subregional areas. It is pointed out that not all students can access the e-learning platform, the Indonesian education system is not ready to add online learning quickly, many rural students do not have connectivity, internet connection is still a luxurious thing in remote places, and many low-income students do not have access to the devices needed to use gadgets to access the e-learning platform.

From the literature study it is known that Indonesia faces some obstacles to replicate the technological successes that have occurred in other sectors and in other countries.

Barriers on the supply side include:

- Difficulty to access funding

- High marginal costs, particularly for acquiring and retaining new customers

- Lack of talented resources to develop and maintain products

This is coupled with obstacles on the demand side, including:

- Low willingness to pay from schools and parents

- Lack of digital literacy, especially on the education provider side

- Poor digital infrastructure, which limits connectivity in remote areas and download speeds across Indonesia

- Overlapping responsibilities between local and central government for new education instruments

- Limited capacity of the general education system as well

- Lack of incentive to appreciate the potential of elearning products

- In addition, underdeveloped consumer protection regulations in Indonesia, particularly regarding data security and privacy, which can jeopardize student and school data

In addition, there are 5 biggest challenges in the development of $\mathrm{AI}$ in education [14] include:

- The first challenge lies in developing a comprehensive public policy view of AI for sustainable development. The complexity of the technological conditions required to advance in this field requires the alignment of several 
factors and institutions. Public policy must work in partnership to create an ecosystem that serves sustainable development AI.

- The second challenge is ensuring the inclusion and equity of AI in education. Several major constraints such as basic technology infrastructure must be faced to establish the ground conditions for implementing new strategies that utilize AI to enhance learning.

- The third challenge is to prepare teachers for AIpowered education while preparing AI to understand education, although this should be a two-way street: teachers must learn new digital skills to use AI in pedagogical and meaningful ways and AI developers must learn how teachers work and create solutions that are sustainable in real life environments.

- The fourth challenge is to develop a quality and inclusive data system. If we go towards datafication education, data quality should be our main concern. It is imperative to develop country's capacity to improve data collection and systematization. The development of AI should be an opportunity to increase the importance of data in the management of the education system.

- The fifth challenge relates to ethics and transparency in data collection, use and dissemination. AI opens up many ethical concerns regarding access to education systems, recommendations to individual students, concentration of personal data, responsibility, impact on work, data privacy, and ownership of data feeding algorithms. As such, AI regulations will require public discussion on ethics, accountability, transparency and security. Therefore, to overcome and anticipate future challenges of $\mathrm{AI}$ in education. Holistic education management is needed from government level to teachers.

In addition, SWOT analysis on Education Technology prospect in Indonesia can be seen in following table 3 .

TABLE III. SWOT ANALYSIS ON EDUCATION TECHNOLOGY

\begin{tabular}{|c|c|c|c|}
\hline STRENGTH & WEAKNESS & OPPORTUNITY & THREAT \\
\hline 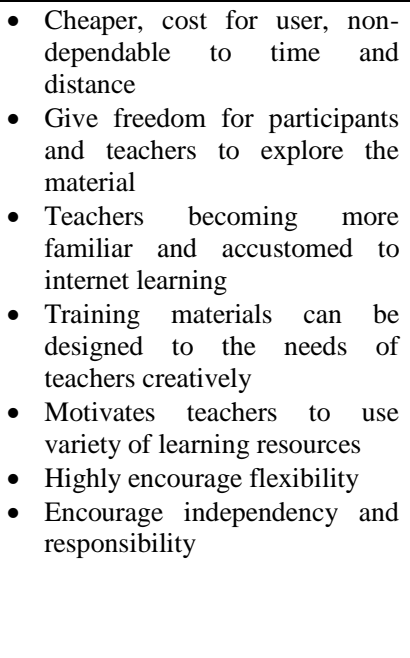 & $\begin{array}{l}\text { - Uneven stability of internet } \\
\text { accessibility of the key role } \\
\text { during online teaching } \\
\text { - Lack of interaction time } \\
\text { with the teacher } \\
\text { - Teacher awareness of the } \\
\text { importance of increasing } \\
\text { teacher ICT competence is } \\
\text { not evenly distributed } \\
\text { - Participants need more } \\
\text { intensive time in learning/ } \\
\text { understanding educational } \\
\text { materials } \\
\text { - Cannot participate directly, } \\
\text { and if there are difficulties } \\
\text { they cannot get direct } \\
\text { guidance } \\
\text { Uneven awareness of the } \\
\text { importance on increasing } \\
\text { teacher's ICT competency }\end{array}$ & $\begin{array}{l}\text { - Industrial revolution } 4.0 \\
\text { - Joint ministerial decree } 4 \\
\text { - Government's instruction } \\
\text { to encourage new literacy } \\
\text { - Pursue towards blended } \\
\text { learning } \\
\text { - Streamline the state } \\
\text { budget to conduct offline } \\
\text { teaching } \\
\text { - Expanding training } \\
\text { opportunities for teachers } \\
\text { to improve their ICT } \\
\text { competency } \\
\text { - Development and insight } \\
\text { and knowledge towards } \\
\text { digital lifestyle } \\
\text { - Self-development } \\
\text { opportunities for teachers } \\
\text { - Development of public } \\
\text { policy on AI }\end{array}$ & 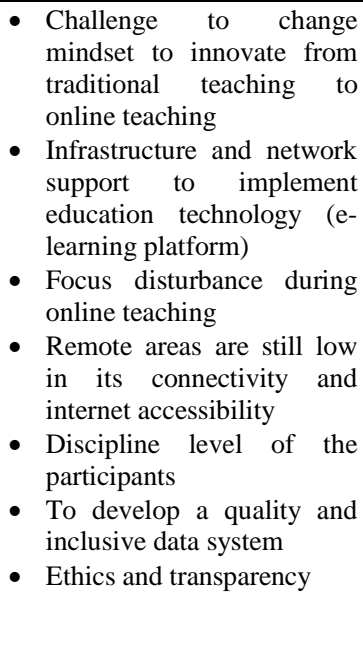 \\
\hline
\end{tabular}

\section{CONCLUSION}

This study uses a literature study and also data mining approach to determine the implementation of artificial intelligence in education. After collecting data through the study of literature, then an analysis of the implementation of artificial intelligence is carried out. The aim is to analyze and explore the artificial intelligence system in education through the SWOT method to prepare future challenges. In this study, current insights and the futuristic perspective of AI have been explored with the Google trends approach and literature study. This study also observes that 5 platforms used massively in Indonesia with related keywords are evaluated, it is observed that with the SWOT approach, AI as a component of the education process, AI can encourage capacity building and capabilities of Indonesian students in the future.

It is very clear that $\mathrm{AI}$ and other superior $\mathrm{AI}$ technologies are here to lighten human life and contribute to the advancement of human progress. However, we must not be satisfied with the idea that technology adaptation is good by default; instead, we need to develop a critical attitude before fully integrating AI into the educational process. As part of this critical attitude, first, ensure the inclusive and equitable use of AI in education. Second, utilize AI to improve education and learning. Third, promote the development of skills for work and life in the AI era. Fourth, maintaining the use of transparent and auditable education data. 


\section{ACKNOWLEDGMENT}

The authors would like to take this opportunity to thank you for your effort and expertise as a reviewer. Your help enabled us to meet the scheduled time and to maintain the standards of peer- reviewed journals. The authors would like to thank National Institute of Public Administration (Polytechnic STIA LAN Jakarta), which has provided research facilities and space.

\section{REFERENCES}

[1] S. Sundvall, "Artificial intelligence," in Critical Terms in Futures Studies, 2019

[2] M. Housman, "Why 'augmented intelligence' is a better way to describe AI," AINews, 2018. [Online]. Retrieved from: https://www.artificialintelligence-news.com/2018/05/24/whyaugmented-intelligence-is-a-betterway-to-describe-ai/

[3] C. Warwick. "Studying users in digital humanities," in Digital Humanities in Practice, vol. 17, no. (5), pp. 1-21, 2018.

[4] V.V. Nabiyev, Artificial intelligence: Human computer interaction. Turkey: Seçkin Publishing, 2016.
[5] S. Russell and P. Norvig, Artificial intelligence: A modern approach (2nd ed.). Upper Saddle River, NJ: Pearson Education, 2003.

[6] N.J. Nilsson, Principles of artificial intelligence. Burlington, MA: Morgan Kaufmann, 2014.

[7] J.C. Giarratano and G.D. Riley, Expert systems: principles and programming. Pacific Grove, Ca.: Brooks/Cole Publishing Co., 2005.

[8] A.D. Thierer, A. Castillo O'Sullivan, and R. Russell, "Artificial Intelligence and Public Policy," SSRN Electron. J., 2017.

[9] D. Bri, M. Garcia, H. Coll, and J. Lloret. "A study of virtual learning environments," WSEAS Transactions on Advances, vol. 6, no. 1, pp. 3343, 2009.

[10] A.W. Bates, Techonology, E-Learning And Distance Education. London, UK: Routledge Studies in Distance Education, 2005.

[11] S. Graf and B. List, "An evaluation of open source e-learning platforms stressing adaptation issues," Fifth IEEE International Conference on Advanced Learning Technologies (ICALT'05), pp. 163-165. IEEE.

[12] F. Rangkuti, Analisis SWOT Teknik Membedah Kasus Bisnis. Jakarta PT. Gramedia Pustaka Utama, 2006.

[13] B. Ward, F.R. David and F.R. David, Strategic management: A competitive advantage approach, concepts and cases. Malaysia: Pearson, 2018

[14] UNESCO, Artificial Intelligence in Education: Challenges and Opportunities for Sustainable Development. Working Papers on Education Policy, 2019. 